\title{
Next Steps for Conservation Agriculture
}

\author{
John N. Landers ${ }^{1, *}$, Pedro Luiz de Freitas ${ }^{2} \mathbb{D}$, Mauricio Carvalho de Oliveira ${ }^{3}$, Sebastião Pedro da Silva Neto ${ }^{4}$, \\ Ricardo Ralisch ${ }^{5}$ and Eric Alan Kueneman ${ }^{6}$
}

1 Brazilian No-Till System Farmers' Federation (FEBRAPDP), Honorary Director, Brasília 71680-368, Brazil

2 Brazilian Agricultural Research Corporation (Embrapa), Embrapa Solos, Rio de Janeiro 22460-000, Brazil; pedro.freitas@embrapa.br

3 Soil and Water Conservation, Secretariat of Inovation, Sustainable Development and Irrigation, Ministry of Agriculture, Livestock and Food Supply, Brasília 70043-900, Brazil; mauricio.oliveira@agricultura.gov.br

4 Brazilian Agricultural Research Corporation (Embrapa), Embrapa Cerrados, Brasília 70770-901, Brazil; sebastiao.pedro@embrapa.br

5 Agronomy Department, State University of Londrina (UEL), Londrina 86057-970, Brazil; ralisch@uel.br

6 Kueneman Consultancy, West Sacramento, CA 95691, USA; eakueneman@gmail.com

* Correspondence: j.n.landers@gmail.com

\section{check for} updates

Citation: Landers, J.N.; de Freitas, P.L.; de Oliveira, M.C.; da Silva Neto, S.P.; Ralisch, R.; Kueneman, E.A. Next Steps for Conservation Agriculture. Agronomy 2021, 11, 2496. https:// doi.org/10.3390/agronomy11122496

Academic Editors: Emilio J. Gonzalez-Sanchez, Amir Kassam, Gottlieb Basch, Hafiz Muminjanov, Antonio Rodríguez-Lizana and Rosa María Carbonell-Bojollo

Received: 1 October 2021

Accepted: 25 November 2021

Published: 9 December 2021

Publisher's Note: MDPI stays neutral with regard to jurisdictional claims in published maps and institutional affiliations.

Copyright: (C) 2021 by the authors Licensee MDPI, Basel, Switzerland. This article is an open access article distributed under the terms and conditions of the Creative Commons Attribution (CC BY) license (https:/ / creativecommons.org/licenses/by/ $4.0 /)$.

\begin{abstract}
The origins, history, and recent advances in Conservation Agriculture (CA) are reported. CA is now practiced worldwide on some 200 million hectares, important for mitigating climate change and ensuring food security. Its bedrock is Zero Tillage (ZT) with crop rotation and retention of crop residues. CA approaches Organic Agriculture (OA) when coupled to biological control providing opportunity for OA to become truly sustainable. Ley Farming (LF) and agroforestry with ZT are important for carbon sequestration and land use intensification. Hidden cost: each ton of carbon immobilizes $83 \mathrm{~kg}$ of N, $29 \mathrm{~kg}$ of P, and $14 \mathrm{~kg}$ of S. Industry-backed Regenerative Agriculture (RA) variants have no scientific definition, but generally adopt CA. Sustainable, profitable, and compatible new technologies are emerging and CA needs to embrace them to present a holistic, sustainable package to the farmer. How? A single definition for agricultural sustainability via a multi-stakeholder world congress would standardize certification and de-confuse the market. RA describes exactly what CA does for soil health and all farmers need to unite around a new "Combined Regenerative Agriculture" (CRA) to lobby for adequate payments for environmental services. Expansion of CA is critical for world sustainability. Many gaps and constraints exist, especially for smallholders.
\end{abstract}

Keywords: land use intensification; no-tillage farming; off-farm benefits; organic agriculture; payments for environmental services; regenerative agriculture; soil biology; soil disturbance; zero tillage

\section{Introduction}

This concept paper is not a literature review but uses references to support its precepts. The text expresses the concern that the world has assimilated the principles of Conservation Agriculture (CA) but has been (partly) blinkered to other compatible and sustainable agricultural practices that could be combined with $\mathrm{CA}$ and generate higher profits for the farmer. All new concepts trigger resistance, but we here expound the benefits to be obtained by expanding the practice of CA with additional practices that do not conflict with, but add to, CA, thus giving the farmer a holistic concept for climate-smart agriculture. This is also compatible with Regenerative Agriculture (RA) and Organic Agriculture (OA), providing they accept the three principles of CA.

During the First World Congress on Conservation Agriculture (WCCA), in a multistakeholder event, held in Madrid in 2001, the concept of CA was consecrated in the Declaration of Madrid [1]. The term CA amalgamated the existing concepts of "direct drilling" (UK), "no-till or no-tillage" (USA), and "sistema plantio direto" (Brazil). 
The most recent definition of CA by the FAO is found as [2]: "Conservation Agriculture is a farming system that promotes minimum soil disturbance (i.e., no tillage), maintenance of a permanent soil cover, and diversification of plant species. It enhances biodiversity and natural biological processes above and below the ground surface, which contribute to increased water and nutrient use efficiency and to improved and sustained crop production". The three principles (pillars) of CA are defined as:

- Minimum mechanical soil disturbance (i.e., no-tillage and direct seeding) through direct seed and/or fertilizer placement;

- $\quad$ permanent soil organic cover (at least 30 percent) with crop residues and/or cover crops; and

- $\quad$ species diversification through varied crop sequences and associations involving at least three different crops.

Four overarching quotations from the Declaration of Madrid declaration are as follows:

(i) Develop compensatory support mechanisms for the environmental services, which CA provides.

(ii) The promotion of alternatives to overgrazing and the inclusion of rotations with high quality pastures in CA project plans.

(iii) This technique being covered by the terms direct drilling, zero tillage, no-tillage, and no-till.

(iv) This Congress calls upon politicians, international institutions, environmentalists, farmers, private industry, and society as a whole, to recognize that the conservation of natural resources is the co-responsibility - past, present and future-of all sectors of society in the proportion that they consume products resulting from the exploitation of these resources. Furthermore, it calls upon society, through these stakeholders, to conceive and enact appropriate long-term strategies for CA and to support, further develop and embrace its concepts. They are the most appropriate means of ensuring the continuity of the land's ongoing capacities to yield food, other agricultural products, water, and environmental benefits in perpetuity. It follows that those environmental benefits provided by farmers practicing CA should be recognized and recompensed by society.

Since Zero Tillage (ZT) is sine qua non to CA, the authors refer to this technology as Zero Tillage Conservation Agriculture (ZT/CA), to remove any idea that CA will work without ZT. The above declaration establishes ZT, NT, and CA as non-equivalent terms, all referred to herein as $\mathrm{ZT} / \mathrm{CA}$.

The worldwide adoption of Sustainable Soil Management (SSM) practices and techniques, principally under CA, has become a well-known fact [3]. Drawing considerably from a Brazilian perspective, the authors analyze different aspects for the evolution of CA into a broader-based combination of technologies leading to a sustainable agriculture under one umbrella, with the aim of facilitating farmers' access to eco-efficient farm practices/technologies and their certification. The next goals in CA must encompass significantly increased contributions to the reduction of global warming and biodiversity loss and to the world's food security. Thus, reductions in net Greenhouse Gas (GHG) emissions and increased yields per unit area are paramount, where Integrated Crop Livestock Farming with Zero Tillage (iCLZT), included in CA, agroforestry, zero deforestation, and Sustainable Land Use Intensification with CA (CA/SLUI) are also key [4].

For the next steps to advance the adoption of CA, we developed the following objectives:

1. To broaden the base of CA by embracing all other sustainable and profitable practices or technologies, even if this means coming to terms with RA and OA and adopting a new, wider, denomination.

2. To demonstrate the need to, and delineate, a set of farming practices that are sustainable and profitable under their current denominations (CA, RA, and OA), separately, if necessary. 
3. To give the farmer a single concept within which he/she can develop his/her own sustainable and profitable system, specific for his/her farm.

4. To replace the current myriad definitions of agricultural sustainability by one global definition, with regional versions, valid for all farming systems and product certifications.

5. To create industry and consumer confidence in sustainable-certified farm products and simplify their certification.

6. To generate a World Congress on Sustainable Agricultural Practices to consecrate the above.

Fulfilment of these objectives would lead to reductions in GHG emissions, improved farm profits, and better food security. The combination of ZT/CA practices brings a series of on- and off-farm benefits. On-farm, the first is erosion control with high rainfall infiltration, the second is lower production costs, the third, enhanced soil biological activity, and, finally, earlier planting. What farmer could ask for more?

Besides improved efficiency of the technology per se, the next steps for CA promotion must encompass significantly increased contributions to the reduction of global warming and to the world's food security. This will come mostly by increasing the area under sustainable practices and the total volume of continued increases in agricultural production and climate-smart agriculture [5].

A fundamental change in approach is required, to move on from that of addressing negative to a systems approach, adjusting the system to prevent their expression [6]. Besides the three pillars of CA in its definition, improved soil health is also imperative and implicit if CA principles are followed. This is not the general case today, so there is ample room for advance.

Thierfelder and others [5] believe that for ZT/CA to make an impact on smallholder farmers worldwide, whose constraints are many, extensionists need to be very well trained and supported to deal with such highly complex systems. Here, Non-Governmental Organizations (NGOs) and Payment of Environmental Services (PES) can make a large difference by raising poor farmers out of poverty with ZT/CA and other Nature-Based Solution (NbS) practices [7]. Technology has long been available worldwide for manual and animal traction systems [8]. For all farmers, the complete adoption of CA principles and other recognized sustainable practices should qualify for the payment of environmental services (PES) under certification recognized by governments or other organizations [9].

\subsection{Nomenclature and Definitions}

Here, we deal with all farming systems (CA, RA, or OA) that adopt ZT/CA pillars. Derpsch and others [10] defined the nomenclature within CA in conformity with the original Madrid Declaration and, in a later publication [11], standardized research methods to establish a level playing field for comparing research results, adopting NT as the standard term, equating the terms zero tillage, no-tillage, and no-till.

The basic principles of ZT/CA are universal in terms of soil, climate, biome, topography, cultural, and socio-economical aspects. Technical solutions, however, depend on local soil/climate conditions and on the ability of farmers and their advisors to adopt the best practices and tools available. OA has a detailed set of guidelines set up by the FAO [12] that prohibits the use of transgenic (genetically modified-a misnomer) varieties, manufactured fertilizers, and chemicals, but allows import of biomass.

There are far too many definitions of RA, according to different interest groups; an overall scientific definition (with multi-stakeholder participation) is urgently needed and still lacking, while $[13,14]$ come close: " $R A$ comprises system-based conservation agriculture, which includes no-till farming in conjunction with residue mulching, cover cropping, integrated nutrient and pest management, complex rotations, and integration of crops with trees and livestock", who also observe that RA needs site-specific packages. This lacks the multi-stakeholder consensus of the Madrid Declaration [1].

Unilever [15] mentions: (i) positive impacts on soil health, water and air quality, carbon capture, and biodiversity; (ii) protection and improvement of community environment and 
wellbeing; (iii) minimizing resource input and producing enough quality food for present and future needs; and (iv) optimizing the use of renewable resources while minimizing the use of non-renewables but fails to mention CA or its principles.

The Center for Regenerative Agriculture and Resilient Systems at California State University at Chico [16] has a wider definition: "Regenerative agriculture practices are those that have the potential to move landscapes in the direction of increased functionality by adhering to one or more of the principles of soil health, along with enhancing the synergies of ecosystem processes". The Rodale Institute [17], that coined the name RA, states: "Regenerative organic agriculture not only maintains resources but improves them", and indicates soil health as the principal indicator, but does not mention CA or zero tillage, without which, in the authors' opinion, OA cannot be sustainable. Additionally, working examples exist [18]. The need for scientific definition is required for scaling up of adoption for approved sustainable practices.

\subsection{The Origins of $C A$}

Direct drilling using paraquat herbicide as a pre-plant burndown was first practiced by farmers in the United Kingdom after paraquat's launch in 1962 [19] but lost this ground after straw burning was banned in the 1990s [11], because the drills then available could not handle heavy wheat straw residues. The technology gained popularity in USA after the successful cultivation of corn in Kentucky [20] under the name of "no-till farming". The first successful farmer in South America was Herbert Bartz in the State of Paraná, Brazil, in 1972, who then called the practice "plantio direto" (direct planting) [21]. This was further developed by the Agronomic Institute of Paraná (IAPAR) and published in 1981 in a bulletin entitled "Plantio Direto".

From these two beginnings, the technology developed in North and South America with later consolidating contributions of research institutions, such as IAPAR [22] in Brazil, the Conservation Tillage Information Centre (CTIC) at Purdue University, IN, the USDA's Natural Resources Conservation Service (NRCS), and other land grant universities in the USA, as well as Canadian and Brazilian universities, who played a prominent role, collaborating with farmers in the development and promotion of no-till in North and South America, liaising with various other research institutions [23,24]. These players associated the concept of direct drilling/planting with the need for maintaining year-round soil cover. This soil and weed management system has achieved the highest level to date in annual crop sustainability worldwide. Later, some proponents used the more scientific terms of no-tillage or zero tillage [25].

This fundamental innovation changed modern agriculture forever and the paradigm change involved represents the turning point to achieving sustainability in annual crop farming $[6,26]$. Maximizing rainfall infiltration and minimizing erosive runoff reduced the high costs of mechanical erosion controls [27] plus the elimination of heavy land preparation costs and a yield boost from earlier planting [28], also occurring in the more recent CA/SLUI system [29-31]. This results in higher yields, counterbalancing any tendency to initial yield reduction due to inexperience with the new technology. This also disproves the idea that "yield is king", favored by input and machinery industries. These impacts, generating incremental profit, were the driving forces behind the unprecedented velocity of adoption of this paradigm-breaking technology.

The wide-scale adoption of CA approaches by large and medium-sized farmers in many field-crop-based agriculture systems has become a well-known fact [3]. The crop rotation and permanent soil coverage elements of FAO-based CA are not always consistently adopted with CA-linked practices. Strip tillage is popular with many farmers in North America but generally results in greater soil disturbance than direct seeding into crop or pasture residues and may not comply with minimum disturbance in $15 \mathrm{~cm}$ strips or $25 \%$ of crop area [2].

There are compelling examples of up-scaled adoption now emerging in South Asia after $30+$ years of research and development originating from the Rice/Wheat Consortium 
followed by $10+$ years of strong national and regional programs such as the Cereal Systems Initiative for South Asia (CSISA) and Sustainable and Resilient Farming Systems Intensification in the Eastern Gangetic Plains (SRFSI) [18]. Even Sub-Saharan Africa is awakening, such as the adoption of CA by maize-based farmers in Zambia, Kenya, and Uganda enabled by training from the Conservation Farming Unit (Lusaka, Zambia) with long-term funding primarily from NORAD and then DiFD. In Brazil and Paraguay, many smallholder farmers of less than 50 hectares have adopted ZT/CA for over twenty-five years [32]. Most of these farmers are mechanized and some use manual hand-jab and animal traction planters or drills. Smallholder farmers dedicated to the production of vegetables have adopted, in the last twenty years, the no-tillage systems for vegetable production [33].

The recent FAO and ITPS [34] publication is a welcome and monumental contribution to defining sustainable farm practices for $C$ sequestration.

Since $\mathrm{ZT}$ is indispensable to $\mathrm{CA}$, to emphasize this fundamental concept, these authors follow the example of Landers and others [35] and use the term ZT/CA. This technology is now fundamental to achieving sustainability in all field crops.

We quote Dr. Norman Borlaug on a visit to Brazil in 1995, when he saw vast areas of ZT/CA:"I am convinced that what is occurring in the Cerrado is one of the most spectacular events of agricultural development that has occurred in the world in the last 100 years. ... The principal impact of this event on food production is yet to be felt. Its full impact will become gradually evident over the next two decades ... I venture to predict that by the year 2010 there will be a tremendous quantity of basic grains - rice, maize, sorghum, soybeans, and common beans, to be exported to the most diverse countries in the world, that will have been produced in the Cerrado. I believe that the production technology, such as minimum tillage and no-tillage that you are introducing to the Cerrado has special significance by being, in itself, a conservation method of special excellence" [36]. Note the lack of distinction between minimum and zero tillage that confuses people to this day - minimum tillage was not then used, nor today, in Brazilian row crops. There will be a spurious short-term crop response to tillage, as oxidized Soil Organic Matter (SOM) releases nutrients, but these have to be replaced and this cost is not taken into account. This is the reciprocal of the process described by Kirkby and others [37].

\subsection{Recent Evolution}

RA is a new broad awakening of the food industry to environmental values, demanded by the consumer, i.e., from the bottom up. As such, it should be welcomed. Wide industry support is related directly to consumers demanding more sustainable agricultural products, especially in light of climate change. It is not a direct threat to the concept of CA and its bedrock ZT as, in general, it embodies these principles, either explicitly or implicitly. RA represents, rather, a gateway for the evolution of CA to a broader scope and a more meaningful contribution to sustainability.

Additionally, the term "regenerative" describes exactly what abstaining from soil tillage does for soil health, including erosion control and maximizing soil biological activity, nutrient efficiency, aquifer recharge, and other beneficial outcomes. However, the term "conservation" in CA harks back to the Dust Bowl and mechanical solutions for erosion control. It is now apposite to change "conservation" to "regenerative". However, for this to happen, the various exponents of RA have to evolve from jargon [6] for marketing to come up with either one or several scientific definitions for the sustainable practices involved, the latter being a more pragmatic approach, to short-circuit long and possibly acrimonious discussions between different groupings under the existing RA banner. What cannot be a compromise is to continue using a poorly defined technology for marketing purposes. It is expected that food and packaging industries espousing this approach would see significant medium-term gains in consumer confidence, and hence sales. In the USA, there is already an example of term abuse. Marketing products as "natural" seems to attract buyers without any qualifiers. Even the FAO has found common ground with The Nature Conservancy (TNC) to suggest a nuanced approach, with "nature-based solutions". Failure 
to define RA will likely at times be harmful to society when sustainable food systems are urgently needed.

\subsection{Expansion of $C A$}

As of 2001, the FAO embarked upon a vigorous dissemination program worldwide, setting up networks in the Americas, Africa, Asia, and Europe. The resulting adoption today is close to 200 million hectares worldwide (extrapolated from Kassam and others [3]). These authors show, for the agricultural year 2015/2016, in millions of hectares, the USA (43), Brazil (32), Argentina (29), and Canada (19) in the Americas as world leaders, in mostly medium and large commercial farms, but with a notable contingent of smallholder mechanized farmers in Brazil, Paraguay, and other southern cone countries for the last fifteen years.

The recent advances in all of Europe have been slow but accelerating in the last five years, also in millions of hectares, with Spain (1.0) leading, France (0.7), the UK (0.6), and smaller adoption in other West European countries. Eastern Europe is led by Russia (6) and Kazakhstan (3), on Chernozems (Mollisols in the US soil taxonomy), but growing expression in other countries of the region. Europe is well supported by ECAF and has a notable annual promotion event, "Groundswell", in the UK that has now adopted RA.

There have been notable advances in Australia (18) in low-rainfall wheat, due to water economy and higher yields. This country is also a world leader in Controlled Traffic Farming (CTF) [38]. In Asia, advances predominate in China (9) and India (3.5), emphasizing smallholder mechanized farmers. In Africa, South Africa (1.6), Zambia (0.6), and Kenya (0.6) lead, with a mix of commercial and smallholder (subsistence) farmers. Thierfelder and others [5] reported that adoption of CA has been more challenging, mainly due to community grazing rights on crop residues.

After 50 years, zero tillage (ZT or no-till), the bedrock of CA, is déjà vu in the southern cone of South America and USA/Canada. However, ZT/CA is not just leaving the soil protected with residues or cover crops and planting/drilling crops through them. Quality $\mathrm{ZT} / \mathrm{CA}$ also requires a pluri-annual rotation, that is frequently absent in practice, due to rainfall limitations for a second crop in some ecoregions or insistence on repeating the most profitable crop year after year. The current recommendation for CA includes three crops in a rotation, with no time limit [2].

CA is also complemented informally by incorporating new compatible and sustainable technologies. Farmers, including those who adopted organic systems, are learning how to incorporate innovative biological controls for disease and pest control and non-chemical systems for weed control, e.g., laser robotics [39]. Additionally, there are self-cleaning horizontal discs for inter-row weeding and high-voltage electric shocks [18] or flame throwers [40] for pre-plant desiccation. In addition, the use of certain rock meals as soil conditioners is showing promise to substitute chemical fertilizers [41,42]. These innovations reduce pesticide and fertilizer use, where the Farmer Responsibility Index underlines significant recent reductions in chemical hazards per ton of production, due to yield increases, improved application efficiency and less, or the absence of, noxious chemicals [43]. The success of eschewing soil tillage gave birth to new paradigms, mostly developed in the Americas.

Early tropical ZT was tested in the humid tropics at the International Institute for Tropical Agriculture (IITA) in Nigeria [44]. The studies confirmed that eliminating tillage with continuous ground cover and crop rotation, fulfilling CA principles, was essential for sustainable field crop intensification without fallows. The program used the revolutionary "rolling punch planter" for ZT/CA [45]. It was a brilliant, revolutionary concept, with various later imitators, that had little success, possibly due to the comparatively higher investment cost compared to the alternative hand jab planter, which could also apply fertilizer [46]. 


\section{Off-Farm Benefits of CA and Payments for Environmental Services}

PES needs to have legislative support. As an example, Brazil recently approved the award of farmer certificates for PES by a presidential decree [47]. This is designed to give access to carbon credits for $\mathrm{ZT} / \mathrm{CA}$ and reforestation and other environmental services via the stock market. In many countries this may be a thorny process, as the European Commission [48] still has no overarching legislation on this to date.

The area certified under hundreds of sustainability standards worldwide was estimated by the Chicago Council on Global Affairs [49] to be about 80 million hectares, or only two per cent of total world agricultural area. This plethora of different requirements to prove sustainability can be resolved for carbon sequestration by adopting the new FAO and ITPS manual on NbS practices [34]. This justifies a call for a World Congress on Sustainable Agricultural Practices (see Recommendations section below). Carbon sequestration is not the only environmental service that farmers provide (see below), nevertheless, the current emphasis on RA's contribution to carbon sequestration has blinded the public to all of the many other environmental services provided by farmers, listed above.

Since the emission of GHGs by annual crops under ZT/CA is also reduced by other mechanisms, it must be recognized that ZT/CA contributes to reducing global warming outside that quoted by Rattan Lal [50] for carbon sequestration in soils and crop residues. The principal additions would be:

(i) Forty to fifty percent reduced fuel consumption [51].

(ii) Land use intensification (higher yields mitigating the demand for de-forestation) [52].

(iii) Reduced methane emissions from cattle on quality pastures in Ley Farming (LF) [53].

(iv) Increased albedo of surface residue, reflecting more of the Sun's rays back to space, thus reducing the amount of the Sun's energy absorbed by the Earth's surface [54].

(v) Increased aquifer recharge.

(vi) Reduced maintenance of rural roads [55].

(vii) Reduced cost of municipal water treatment [54].

(viii) Reduced use of inputs eliminates the GHG emissions in their manufacture and transport.

A list of other, mostly un-remunerated farmer environmental services, is given below:

- Erosion minimized, soil life extended to sustainable levels, ensuring food safety for future generations.

- Sustainable intensification of land use mitigates land clearing.

- Guarantee of quality and quantity of municipal water supply.

- Mitigation of flood risks by extending the time of concentration.

- Reduction in reservoir and waterway silting.

- Improved overwintering feed and shelter for wild fauna (lost grain and weed seeds).

In support of RA, private industry in the USA has already developed a "predictive modeling (IT) technology" to measure carbon sequestration increments at field and farm levels [56]. Other such models could support different environmental services, as an expression of industry's environmental conscience. Carbon offsets have the downside that they could permit polluters to continue polluting. In Brazil, and some other countries, schemes by local authorities to guarantee water quality and quantity for urban dwellers by paying for the adoption of ZT/CA on their supply watersheds have been successful in limited areas of water scarcity. This trend will grow rapidly with the intensification of extreme events due to climate change.

Lal and others [57] considered ZT/CA to be the best way of achieving effective soil $\mathrm{C}$ sequestration, promoting the improvement of soil productivity and soil function. This can be approximately $350 \mathrm{kgC} \mathrm{ha}^{-1}$ year $^{-1}$ to a depth of $20 \mathrm{~cm}$ in the Brazilian tropical savannahs (Cerrados), and up to about $480 \mathrm{kgC} \mathrm{ha}^{-1}$ year $^{-1}$ in sub-tropical regions [58]. Extending this figure to deep soil sequestration up to $1.5 \mathrm{~m}$ would probably more than double this, due to annual crop root decay and, to a lesser extent, root exudates. Reforestation is the most effective solution for $\mathrm{C}$ sequestration, amounting to $6 \mathrm{MgC} \mathrm{ha}^{-1} \mathrm{yr}^{-1}$ [59]. 
The FAO and ITPS [34] ranked reforestation and natural forest management as about three times as efficient in their Climate Modification Potential (CMP) as the best agricultural solutions (avoiding grassland conversion, cover crops, biochar, alley cropping, and cropland nutrient management), while avoiding de-forestation approximates to only about one tenth of the first two. Land use intensification (LUI), resulting from higher yields, is an important driver here.

However, to date, the sum of all these mechanisms appears to lack the volume to cover the ambitious targets of the UN Strategic Development Goals (SDGs) [60], or the UN Evergreening Campaign [61] and other laudable targets. SDGs also have to accommodate population growth and increased consumption per capita in developing and under-developed nations. In addition, PES for ZT/CA adoption in new areas will be crucial to the attainment of these goals.

On the other hand, classical economists would argue that ZT/CA generates incremental profits and therefore should not receive PES. In fact, market forces exert downward pressure on agricultural prices when farm profits rise. However, of the series of off-farm benefits of ZT/CA listed above, that generate public benefits, only carbon sequestration and urban water supply, guaranteed by ZT/CA, receive (some) PES.

If a full accounting were performed, on the value of environmental services supplied by farmers. This is a challenge for economists, both in quantification of these multiple impacts and to devise policies that keep food prices stable, while realizing PES to farmers. As a support for PES, it is important to inform consumers of the carbon footprint and notable reductions in chemical hazards in the food they consume [43].

\section{Technical Aspects}

\subsection{The Game-Changer}

The real game-changer is the quantification of the C:N:P:S ratio in stable SOM, which is 10,000:833:200:143 in comparative atomic weights [37]. This permits calculation of the incremental nutrients tied up in stable SOM, amounting to approximately $83 \mathrm{~kg}$ of N, $29 \mathrm{~kg}$ of $\mathrm{P}$, and $14 \mathrm{~kg}$ of $S$ per ton of carbon sequestered. The value of this is about USD 150 per ton of carbon in Brazil at October 2021 prices. When incrementing soil organic carbon stocks, the loss of available nutrients goes unperceived by the farmer, who incorporates these amounts in his/her chemical or organic fertilizer application or suffers insidious depletion of his/her soil nutrient stocks. The cost of this contribution to reducing $\mathrm{CO}_{2}$ emissions has not yet been incorporated in PES to farmers.

Kirkby and others [37], working in Australia with lightly incorporated residues and application, or not, of NPS in excess of crop removal, showed a total six-year net gain in stable $C$ of organic matter to a $1.6 \mathrm{~m}$ depth of $5.5 \mathrm{t} \mathrm{ha}^{-1}$ with NPS applied but a net loss of $2.9 \mathrm{t} \mathrm{ha}^{-1}$ from the $0-10 \mathrm{~cm}$ layer without NPS. This illustrates three important points: (i) that residue incorporation without adequate nutrient replacement causes loss of sol C; (ii) the carbon balance in soil has to be measured to much greater depths than in the majority of studies on this topic; and, (iii) it corroborates Lal, Reicosky, and Hanson [26], that soil tillage causes loss of SOM. A ZT/CA treatment was not included, but the positive implications for ZT/CA are evident.

Pragmatically, the best the ZT/CA farmer can expect is: (i) a small premium for recognized $C$ sequestration mechanisms and (ii) public recognition of his/her role as a Guardian of Natural Resources; in most of Brazil's agricultural areas this amounts to 20\% of the farm plus areas of riparian vegetation. In Paraguay, this is a straight $25 \%$ of farm size and in the Brazilian Amazon, 50\%. Very few other countries in all continents have such un-remunerated obligations for on-farm preservation of native vegetation.

In fact, the Round Table on Responsible Soy (RTRS) certification specifically requires zero de-forestation and exports some 4 million tons of certified soybeans annually to Europe, mostly from South America. This pays farmers a minimal premium of about USD 2.00 per ton. To assuage this paltry token of financial recognition for responsible farming, consumers could at least formally recognize the responsible farmers' role in mitigating 
$\mathrm{CO}_{2}$ emissions and avoiding de-forestation, plus all the other freebies of the off-farm benefits bestowed upon society by ZT/CA (see above). Such public recognition of their roles would not be missed. However, directly or indirectly, these impacts are caused by society's ever-increasing demands for agricultural products, requiring $70 \%$ growth in the first half of the 21st century [6]. If this consumer society could attain zero population growth, the farmer's role would be simply to provide food and other products at lower prices to reduce poverty.

Another aspect of this equation is the current worsening problem of $\mathrm{P}$ pollution in European groundwater due to the high P content of animal manures re-cycled on agricultural land; the obvious solution is to produce animal products close to the feed source and export meat and dairy products from soya- and maize-exporting countries that do not have shallow groundwater.

\subsection{Important Parts of the Solution}

Macedo [62] showed that, by incorporating the basic principles of ZT/CA, LF, also termed iCLZT, showed the viability of converting degraded pastures to LF. Landers, Clay, and Weiss [63] showed a reduced demand for area expansion by land clearing of between 0.8 and 2.5 ha per hectare of LF. As a result of the Landers and Weiss report [64], Brazil set up a subsidized investment credit line for LF and for agroforestry with LF (iCLF), now absorbed in Brazilian Plan for Adaptation and Low Carbon Emission in Agriculture (Brazil's ABC Plan), described by Gurgel and Laurenzana [65]

According to estimates of Polidoro and others [66], Brazil has 17.23 Mha of iCLF implanted up to 2021. In the most optimistic scenario, these authors estimate an area of 29.3 Mha by 2030, meaning an annual increase of 1.19 Mha. Additionally, Landers and others [4] demonstrated how pastures in LF rotations are renovated with the residual fertility from the crop phase. Based on five twenty-year models of LF in wet/dry and humid tropical Brazil, Landers [45] showed a $94 \%$ higher average pasture carrying capacity in animal units (AUs) per hectare, giving an average CA/SLUI index of 2:1.

Improved pasture quality also leads to a reduction in methane emissions per kilogram of beef of the order of $33 \%$ [54]. Here lies considerable potential for mitigating global warming, but it demands investment in watering, handling facilities, and fences, plus higher management capacity. A far greater impact on GHG emissions is achieved by incorporating agroforestry into iCLZT and reforestation is the principal goal of the Evergreening Global Alliance [61] and of Brazil's ABC Plan [65].

Some current examples of technologies compatible with ZT/CA are:

- $\quad$ LF and iCLF (already incorporated in CA) [3].

- Precision agriculture, combining Information Technologies (ITs) for assessing soil attributes, yield mapping, variable rate input application, and drones for detection of pests and weeds, diagnosis of plant diseases, and spot spraying.

- Biological controls of all types.

- Some specific rock meals are used as soil conditioners and to substitute costly fertilizer imports in stable ZT/CA areas [41,43].

- Controlled traffic farming avoids shallow and deep compaction [67].

- Benchmarking with technical indicators [46].

Additionally, more are coming on stream.

\section{3. $C A$ Is Approaching $O A$ and Vice Versa}

To maximize sustainability, OA farmers would benefit from ZT/CA to avoid erosion and maximize soil biological activity and other beneficial effects on soil health. Weed management in OA systems is a challenge and even more so when tillage is excluded [68]. Farmers in the USA and Europe are actively exploring management innovations, including cover crops and mulches, with various levels of success depending on local conditions and specific system needs [5]. It is appreciated that there are situations where planting of cover crops will be difficult for millions of smallholder farmers in Asia and especially in 
Sub-Saharan Africa where, for example, there are often long (6 to 7 months) dry seasons when livestock are released for open grazing. In such situations, farmer options exist under the CA-based Sustainable Intensification (CA/SLUI) approaches where integration of agroforestry technologies can create additional biomass and habitat enhancements for soil health improvements. Such CA/SLUI approaches will fit well under a future CRA banner.

With SOM loss in soil preparation [69], conventional tillage in organic systems tends towards a negative carbon balance, unless they import biomass in the form of mulch, animal manures, biochar, or industrial plant residues, such as rice hulls, sawdust, or wood chips, but this is exported from another system that may, or may not, have a positive carbon balance. Some progressive organic farmers have made the transition to ZT/CA [18]. As a result, to maximize sustainability, OA farmers would benefit from ZT/CA. Weed management in OA systems is a challenge and even more so when tillage is excluded [34].

New, profitable, and sustainable technologies have come on stream since 2001 that are compatible with ZT/CA, RA, and OA; they need to be incorporated under the ZT/CA or a new CRA umbrella. Otherwise, farmers will go elsewhere for technical information that leads to more profit, e.g., RA, which, explicitly or not, follows ZT/CA principles. The examples below will need to be evaluated by a sustainability index to be elected or developed, requiring minimum levels of erosion control, carbon sequestration, nutrient efficiency, and other indicators, before being incorporated in a list of approved ZT/CAbased sustainable technologies. One index that might be useful here is the Carbon Benefits Index [70]. This list will furnish building blocks by eco-region for farmers to make their own combinations, suited to their farms and local ecology.

\subsection{Challenges for Merging $C A, R A$, and $O A$}

The world does not need the current plethora of hundreds of competing concepts for agricultural sustainability in different certification schemes [48]. This confuses consumers and financial institutions. All farmers need to present a united front on sustainability and its costs to farmers, across the whole spectrum from subsistence to commercial, crop- or livestock-based farms.

The adoption of a single standard for sustainable agricultural practices is fundamental as a uniform base for certification schemes, for compliance with the requirements for loans from (leading) credit institutions, and for the achievement of the targets of the SDGs proposed by the FAO/UN for the Agenda 2030, and the UN Global Alliance for Evergreening, mentioned earlier.

A challenge that needs to be addressed is from the novel label "regenerative agriculture", not yet scientifically defined [13,71] but clearly including ZT/CA principles and various practices of $\mathrm{OA}$. A quite complete description is given by the Regenerative Agriculture Initiative/California State University Chico, and The Carbon Underground [72] as "Regenerative Agriculture describes farming and grazing practices that, among other benefits, reverse climate change by rebuilding SOM and restoring degraded soil biodiversity-resulting in both carbon drawdown and improving the water cycle" and complemented by Regeneration International [73] with a list of accepted concepts. This broad description covers everything that ZT/CA and iCLZT do, except the use of chemicals and transgenic varieties, without enunciating a concise science-based definition of RA or component practices; it does not reiterate the three pillars of the FAO definition of CA. It also lacks wide and formal stakeholder approval, as was obtained for CA in 2001, with the Declaration of Madrid. In fact, ZT/CA does not have recognition as the fulcrum and sine qua non of sustainability in annual cropping. Newton and others [71] differentiate between outcome-based and process-based definitions in RA. In reasons for adoption of RA among practitioner websites, they found the most commonly mentioned outcomes were: aspirations to improve soil health $(86 \%)$, to sequester carbon $(64 \%)$, to increase biodiversity $(46 \%)$, to improve water resources $(46 \%)$, and to improve the social and/or economic wellbeing of communities $(41 \%)$, denoting a high level of awareness and responsibility in practitioners. 
It would be helpful for RA to formally recognize ZT/CA as a sine qua non of agricultural sustainability, especially in the tropics. There also is a need to define additional science-based technologies that differentiate new labels from ZT/CA.

To expand the scope, and hence the definition of $\mathrm{ZT} / \mathrm{CA}$, the following questions need to be addressed: (i) can CA become the umbrella definition for all sustainable technologies? and (ii) how do we adjust the concept to achieve this? The answer to the first is yes, provided a way is found to get RA and OA on board. That may require re-naming the concept as CRA or another suitable name. On the second question, one approach would be a CA base definition, with clarifying adjustments (see Section 4.1, below), and including the Modifications to Update the CA Definition, below, plus the list of approved compatible technologies indicated earlier. The FAO and ITPS Manual would be a useful start [34].

The question needs to be asked: which organization(s) represent(s) RA? CA and OA have a national entity and some regional entities; the former has just completed its 8 th WCCA, held at three-year intervals, and has an FAO-supported Community of Practice (CA-CoP) disseminating information worldwide. The OA is also well organized in a Global Organic Movement, with a three-year Organic World Congress, now in its 20th edition.

Another expressive challenge is convincing the food industry and trader backers of the successful RA campaign to join forces with all adopters of ZT/CA principles under a new CA/RA/OA umbrella, putatively denominated "Combined Regenerative Agriculture" (CRA). Inevitably, concessions will have to be made in developing an all-embracing and much-needed scientific definition for CRA, with different compartments for the different persuasions. This definition would be quantified by including the list of approved sustainable practices mentioned in Section 3.2 that would be according to a minimum score of a sustainability index (to be elected), requiring minimum levels of erosion control, carbon sequestration, nutrient efficiency, the FRI (an all-farm hazard rating [43]), and other requirements, as necessary. To assuage industry's perception of the excessive cost and complications of externally verified formal certifications, CRA would be a self-assessment group exercise, policed by random checks, with heavy fines and exclusion of infractors guilty of false declarations from group participation and exclusion of a group after two infractions, for, say, five years. To create consumer confidence, this process needs to be strict and transparent.

There is still so much to be done to further enhance and up-scale adoption. The growing urgent realization that agriculture must be a major part of addressing the climate change crisis and broader environmental degradation is driving assessment and policy on how best to further incentivize adoption of CA/SLUI across major farming systems. We intend to broaden the discussion and hopefully contribute the knowledge basis for strategic investments, public and private, to make this a reality. Modern Information and Communication Technologies (ICTs), perhaps including blockchain approaches, can open new opportunities for PES to farmers-including smallholders. The 2021 UN Food Systems Summit sets the stage for new visions to be integrated and ratified at the UN Climate Change Conference (COP26, November 2021). CA/SLUI is finally becoming a major tool, not only for sustainable production, but also to pull farm families out of poverty and reduce drivers of climate change.

\subsection{The Unfinished Symphony of Soil Biology}

We are still learning to conduct this symphony. "Think like a rhizosphere" is the new maxim extensionists are now adopting to convey to farmers the complexity of managing the living soil, and its rewards. The principal movements of this symphony are:

- Root exudates solubilize unavailable nutrients.

- Sugars in root exudates feed beneficial microbes.

- Root exudates form crumb structures in the vicinity of roots.

- Improved soil structure supplies more oxygen and increases water-holding capacity, with better root penetration. 
- Earthworms, beetle larvae, soil fungi, and bacteria digest crop residues, and the formers' burrows increase rainfall infiltration and enrich soil with excretions.

- Zero tillage preserves fungal hyphae, old root holes, all soil life, and ground-feeding birds and small mammals.

- Crop residues that are food substrates for soil life eventually form humus.

- Biological controls are advancing fast, with:

- Antagonic fungi, e.g., Trichoderma spp., to control root diseases.

- Parasitic wasps lay eggs on caterpillars, which are killed by wasp larvae.

- $\quad$ Cover crops, like Crotalaria spp., to control nematodes.

- Entomopathogenic fungi, like Beauveria spp., to control various pests.

- Entomopathogenic bacteria, like Bacillus thuringiensis, to control insects and mites.

- Pluri-annual rotations reduce multiplication of pests and diseases.

\subsection{Longevity of the ZT/CA Movement}

This will be meaningfully enhanced by:

- Payment, or at least recognition, of environmental services on- and off-farm is a must.

- Accommodation with RA, OA, and their variants.

- Promoting new compatible, sustainable, and profitable technologies under ZT/CA, CRA, or CA/SLUI.

- More case studies worldwide showing cover crops are profitable over the long term.

- Recognition of the sustainable farmer as a "Guardian of Natural Resources" under his/her stewardship on-farm, with positive off-farm impacts.

\section{Future Perspectives}

As consumers demand greater food traceability, certification and benchmarking will continue to expand, while increasing complexities in soil, water, crop, and livestock management are demanding higher skill levels and widespread use of specialized consultants.

\subsection{Modifications to Update the CA Definition}

It must be considered that the most important of all modifications is to open the scope of CA to embrace all compatible, sustainable, and profitable technologies. The slightly different wordings on the FAO website postings on CA need to be substituted by a single definition on all pages of the website, especially minimum tillage, soil tillage or reduced tillage which must not substitute minimum soil disturbance.

\subsection{The Expansion of Eco-Friendly Farming Systems}

The expansion of CA-based eco-friendly farming systems under CA, RA, OA, or other such systems is crucial to reduce climate change and improve world food security [14].

The establishment of worldwide common denominators for sustainability is indispensable for achieving the UN's Sustainable Development Goals. For this to occur, all denominations of farmers (CA, RA, OA, and others) have to embrace the responsibility to achieve these, which requires a perception of the holistic challenge for world survival, where all denominations of farmers unite to receive world support in their endeavors to reach these goals. This is a co-responsibility of all sectors of society to preserve natural resources in the proportion that they consume products that emanate from the exploitation of these resources, as expressed in the Declaration of Madrid [1].

The big gaps in ZT/CA adoption are in the areas of smallholder farmers in Africa [74] and all other continents, plus subsidized commercial farmers in Western Europe, who resist changes $[75,76]$. The latter cite yield, operating costs, and environmental policies as drivers. However, Brazilians and Paraguayans show considerable adoption by small mechanized farms [8] and this experience points, initially, to erosion control, farmer-tofarmer contact, and farmer associations and cooperatives, plus commercial/press support for dissemination events [77]. In the United States, the USDA [24] and the CTIC have 
provided scientific information to farmers, mirroring effective contributions worldwide from research institutions and universities.

An essential empowerment for the ZT/CA farmer is to receive better prices from sustainable-certified products and this is being driven by big food sector companies like Unilever [15] in Europe, promoting RA. This can be a part of complying with the concept of Essential Sustainable Governance (ESG) being implemented by companies to demonstrate their environmental responsibility and hence grow faster and generate more profit [78]. However, this must come principally from consumer awareness in richer countries.

\section{Recommendations}

As noted above, the world needs a definition platform of sustainable agricultural practices that can be applied across production systems and be context sensitive. Good agriculture practices should be defined in a multi-stakeholder World Congress on Sustainable Agricultural Practices, using the FAO/ITPS's manual of recommended SSM [34] as a model. This should occur in about 2-3 years' time, and its organization would be in parallel with a multi-stakeholder working group to define the methodology of selection and recommend candidate practices for an approved list, to be debated and approved by the above-proposed International Congress. It must be explicit that these approved sustainable practices would be inserted into the synergies of a CA-based system and would not be sustainable alone.

This would create a level playing field worldwide to define this benchmark for general use and to qualify certification schemes to receive PES. The congress organization would be telescoped with the working group. Approved sustainable practices do not stand on their own but must be additional to a CA system.

A few other recommendations are:

- Carbon credits for incremental carbon in SOM from private industry are already being implemented with RA [56] and other farming systems, and are the most obvious, but not the only, form to initiate such social transfers (not subsidies); carbon offsets have the downside that they could permit polluters to continue polluting.

- In Brazil, and some other countries, schemes by local authorities to guarantee urban water quality and quantity by paying for adoption of ZT/CA on their supply watersheds will grow rapidly with the intensification of extreme events as a result of climate change.

- As cover crop results often take years to be perceived and short-term economic pressures prevail, cover crops are not widely included in ZT/CA rotation, but this has been improving in recent years, from estimates of the Sustainable Agriculture Research and Education Program [79]. Long-term financial and physical impact studies are required to accelerate adoption.

- The dicta of the Declaration of Madrid and succeeding WCCA congresses should be fully implemented. There has already been a considerable lag on implementing many of those from the 1st WCCA and climate change requires immediate action.

- Forgetting vanities and accepting RA's embracing of CA principles and working with its several groups towards a scientific definition, which is lacking, thus working towards a unifying framework with formal recognition of CA principles as essential to sustainability.

- Whole-farm certification, and not for individual products, would greatly assist PES, and reduce its operational costs.

- $\quad$ All PES should be direct to farmers.

Author Contributions: Conceptualization and writing, J.N.L.; Review and editing, P.L.d.F.; Review, M.C.d.O., S.P.d.S.N., and R.R.; Global perspectives overview and review, E.A.K. All authors have read and agreed to the published version of the manuscript.

Funding: This research received no external funding. 
Acknowledgments: The authors would like to thank Tony Fischer (Agricultural Scientist, Honorary Fellow, CSIRO, Australia) and Don C. Reicosky (retired USDA/ARS soil scientist, USA) for helpful literature suggestions and comments, Thomas F. Shaxson (land husbandry agronomist, retired FAO, UK) for useful exchanges, and our three reviewers for constructive criticism.

Conflicts of Interest: The authors declare no conflict of interest.

\section{References}

1. Vanelph, S.; Benites, J. Report of the 1st World Congress on Conservation Agriculture; Food and Agriculture Organization of the United Nations (FAO) and the European Conservation Agriculture Federation (ECAF): Madrid, Spain, 2001; Available online: www.act-africa.org/file/newsletters/books_manuals/first-wcca\%20.pdf (accessed on 17 November 2021).

2. Conservation Agriculture. Available online: www.fao.org/conservation-agriculture/en/ (accessed on 17 November 2021).

3. Kassam, A.; Friedrich, T.; Derpsch, R. Global spread of Conservation Agriculture. Int. J. Environ. Stud. 2018, 76, 29-51. [CrossRef]

4. Landers, J.N.; de Freitas, P.L.; Balbino, L.C.; Salton, J.C.; Marchão, R.L. Integration of Crop-Livestock in Conservation Agriculture systems. In Advances in Conservation Agriculture, Burleigh Dodds Series in Agricultural Science; Burleigh Dodds Science Publishing: London, UK, 2020; Volume 1, Chapter 9. [CrossRef]

5. Thierfelder, C.; Chivenge, P.; Mupangwa, W.; Rosenstock, T.S.; Lamanna, C.; Eyre, J.X. How climate-smart is conservation agriculture (CA)? - Its potential to deliver on adaptation, mitigation and productivity on smallholder farms in southern Africa. Food Sec. 2017, 9, 537-560. [CrossRef]

6. Mitchell, J.P.; Reicosky, D.C.; Kueneman, E.A.; Fisher, J.; Beck, D. Conservation agriculture systems. CAB Rev. Perspect. Agric. Vet. Sci. Nutr. Nat. Resour. 2019, 14, 1-25. [CrossRef]

7. Miralles-Wilhelm, F. Nature-Based Solutions in Agriculture-Sustainable Management and Conservation of Land, Water, and Biodiversity; FAO and The Nature Conservancy: Rome, Italy, 2021. [CrossRef]

8. De Ribeiro, M.F.d.S.; Merten, G.H.; Skóra-Neto, F. Plantio direto na palha na pequena propriedade. In Plantio Direto No Brasil; Aldeia Norte: Passo Fundo, Brazil, 1993; pp. 151-158.

9. Prado, R.B.; Fidalgo, E.C.C.; Monteiro, J.M.G.; Schuler, A.E.; Vezzani, F.M.; Garcia, J.R.; de Oliveira, A.P.; Viana, J.H.M.; da Pedreira, B.C.C.G.; da Mendes, I.C.; et al. Current overview and potential applications of the soil ecosystem services approach in Brazil. Pesq. Agropec. Bras. 2016, 51, 1021-1038. [CrossRef]

10. Derpsch, R.; Franzluebbers, A.J.; Duiker, S.W.; Reicosky, D.C.; Koeller, K.; Friedrich, T.; Sturny, W.G.; Sá, J.C.M.; Weiss, K. Why do we need to standardize no-tillage research? Soil Tillage Res. 2014, 137, 16-22. [CrossRef]

11. Derpsch, R.; Friedrich, T.; Landers, J.N.; Rainbow, R.; Reicosky, D.C.; Sa', J.C.M.; Sturny, W.G.; Wall, P.; Ward, R.C.; Weiss, K. About the necessity of adequately defining no-tillage-A discussion paper. In Proceedings of the 5th World Congress of Conservation Agriculture, Brisbane, Australia, 26-29 September 2011; pp. 26-29.

12. FAO. Guidelines for the Production, Processing, Labelling and Marketing of Organically Produced Foods; FAO: Rome, Italy, 2007; Available online: http:/ / www.fao.org/tempref/docrep/fao/010/a1385e/a1385e00.pdf (accessed on 19 October 2021).

13. Cusser, S.; Bahlai, C.; Swinton, S.M.G.; Robertson, P.; Haddad, N.M. Long-term research needed to avoid spurious and misleading trends in sustainability attributes of no-till. Glob. Chang. Biol. 2020, 26, 3715-3725. [CrossRef] [PubMed]

14. Lal, R. The Future of No-Till Farming Systems for Sustainable Agriculture and Food Security. In No-Till Farming Systems for Sustainable Agriculture; Dang, Y., Dalal, R., Menzies, N., Eds.; Springer: Cham, Switzerland, 2020. [CrossRef]

15. The Unilever Regenerative Agriculture Principles. Available online: Assets.unilever.com/files/92ui5egz/production/489410 442380812907bc3d97be02ccda1a44ab4b.pdf/Regenerative-Agriculture-Principles-and-Implementation-Guide-April-2021.pdf (accessed on 20 October 2021).

16. Center for Regenerative Agriculture and Resilient Systems. Available online: https://www.csuchico.edu/regenerativeagriculture/ ra101-section/index.shtml (accessed on 20 October 2021).

17. Regenerative Organic Agriculture. Available online: https://rodaleinstitute.org/why-organic/organic-basics/regenerativeorganic-Agriculture (accessed on 19 October 2021).

18. Landers, J.N.; Challiol, M.; Lanz, S.A. Case study of Zero Tillage Organic Soybean Production in Brazil. Soil Res. 2016, 54, 166-172. [CrossRef]

19. Akhavein, A.A.; Linscott, D.L. The dipyridylium herbicides, paraquat and diquat. In Reviews/Rückstands-Berichte; Gunther, F.A., Ed.; Residue Reviews; Springer: New York, NY, USA, 1968; Volume 23. [CrossRef]

20. Phillips, S.H.; Young, H.M. No-Tillage Farming; Reiman Associates: Milwaukee, WI, USA, 1973; p. 224.

21. Freitas, P.L.; Landers, J.N. The transformation of agriculture in Brazil through development and adoption of Zero Tillage Conservation Agriculture. Int. Soil Water Conserv. Res. 2014, 2, 35-46. [CrossRef]

22. IAPAR. Plantio Direto No Estado Do Paraná; Circular Técnica, 23; IAPAR: Londrina, Brazil, 1981; p. 244.

23. Franzluebbers, A.J. Achieving Soil Organic Carbon Sequestration with Conservation Agricultural Systems in the Southeastern United States. Soil Tillage Res. 2008, 83, 120-147. [CrossRef]

24. Reeves, D.W.; Delaney, D.P. Conservation Rotations for Cotton Production and Carbon Storage. In Proceedings of the Southern Conservation Tillage Conference for Sustainable Agriculture, Auburn, AL, USA, 24-26 June 2002; van Santen, E., Ed.; pp. 344-348. 
25. Freitas, P.L. De Sistema Plantio Direto: Conceitos, Adoção e Fatores Limitantes; [Com. Téc., 31]; Embrapa Solos: Rio de Janeiro, Brazil, 2005; p. 9. Available online: www.infoteca.cnptia.embrapa.br/infoteca/bitstream/doc/855711/1/comtec312005plantiodireto.pdf (accessed on 28 September 2021).

26. Lal, R.; Reicosky, D.L.; Hanson, J.D. Evolution of the plow over 10,000 years and the rationale for no-till farming. Soil Tillage Res. 2007, 93, 1-12. [CrossRef]

27. Blisard, W.N.; Keller, L. An Economic Analysis of Terraces as an Erosion Control Alternative on West Tennessee Farms; Bulletins; University of Tennessee Agricultural Experiment Station: Knoxville, TN, USA, 1983; Available online: https://trace.tennessee. edu/utk_agbulletin/423 (accessed on 17 November 2021).

28. Landers, J.N. Fascículo de Experiências de Plantio Direto no Cerrado (Zero Tillage in the Cerrados); APDC: Goiânia, Brazil, 1994.

29. Erenstein, O.; Laxmi, V. Zero-tillage impacts in India's rice wheat systems: A review. Soil Tillage Res. 2008, 100, 1-14. [CrossRef]

30. Keil, A.; D'Souza, A.; McDonald, A. Zero-tillage as a pathway for sustainable wheat intensification in the Eastern Indo-Gangetic Plains: Does it work in farmers' fields? Food Sec. 2015, 7, 983-1001. [CrossRef]

31. Krishna, V.V.; Veettil, P.C. Productivity and efficiency impacts of conservation tillage in northwest Indo-Gangetic Plains. Agric. Syst. 2014, 127, 126-138. [CrossRef]

32. De dos Ribeiro, M.F.S.; Casao, R., Jr.; De Araujo, A.G.; Figueiredo, P.R. Desenvolvimento de Equipamentos Para o PD em Pequenas Propriedades: A Experiência do IAPAR; IAPAR: Londrina, Brazil, 1998.

33. Fayad, J.A.; Comin, J.J.; Mafra, A.; Kurtz, C.; Fayad, S.J.; Madeira, N.R.; Marchesi, D.R.; Wildner, L.P.; Calegari, A.; Loss, A.; et al. Management of vegetable Conservations Agriculture Systems. In Advances in Conservation Agriculture: Systems and Science; Kassam, A., Ed.; Burleigh Dodds Science Publishing: Cambridge, UK, 2020; pp. 279-326. [CrossRef]

34. FAO and ITPS. Recarbonizing Global Soils: A technical manual of recommended sustainable soil management. In Cropland, Grassland, Integrated Systems, and Farming Approaches_Practices Overview; FAO and ITPS: Rome, Italy, 2021; Volume 3. [CrossRef]

35. Landers, J.N.; Rass, G.; de Freitas, P.L.; Basch, G.; González-Sanchez, E.J.; Tabaglio, V.; Kassan, A.; Derpsch, R.; Friedrich, T. Effects of Zero Tillage (No-Till) Conservation Agriculture on Soil Physical and Biological Properties and Their Contributions to Sustainability. In Proceedings of the European Geosciences Union Meeting, Vienna, Austria, 7-12 April 2013; Geophysical Research Abstracts. 2013; Volume 15. EGU2013-11756-1. Available online: http://meetingorganizer.copernicus.org/EGU2013/ EGU2013-11756-4.pdf (accessed on 30 September 2021).

36. Cardoso, F.P.; Fundação AgriSus, Campinas, Brazil. Personal communication, 2012. Quoting a letter from Dr. Borlaug.

37. Kirkby, C.; Kirkegaard, J.; Richardson, A.E.; Wade, L.; Blanchard, C.; Batten, G. Stable soil organic matter: A comparison of C:N:P:S ratios in Australian and other world soils. Geoderma 2016, 163, 197-208. [CrossRef]

38. Tullberg, J.; Yule, D.F.; McGarry, D. Controlled traffic farming-From research to adoption in Australia. Soil Tillage Res. 2007, 97, 272-281. [CrossRef]

39. Mathiassen, S.; Bak, T.; Christensen, S.; Kudsk, P. The Effect of Laser Treatment as a Weed Control Method. Biosyst. Eng. 2006, 95, 497-505. [CrossRef]

40. Favarato, L.F.; Souza, J.L.; Guarçoni, R.C.; Bahiense, D.V. Flamethrower Application Time in Weed Control. Planta Daninha 2016, 34, 327-332. [CrossRef]

41. Landers, J.N.; Faedo, F.; Martins, E.S. Stone Meal Farm Tests in tropical Brazil. In Agriculture for Development; Tropical Agriculture Association: Newton Stewart, UK, 2021; in press.

42. Manning, D.A.C. Mineral sources of potassium for plant nutrition-A review. Agron. Sustain. Dev. 2012, 30, 281-294. [CrossRef]

43. Landers, J.N.; Bernardes, R.; Bernardes, A.C.; Weiss, A.B.; Aernoudts, L.J.M. The Farm in Numbers-Benchmarking as a tool for improved performance in Conservation Agriculture/Zero Tillage systems in Tropical Brazil. In Proceedings of the 7th WCCA, Rosário, Argentina, 1-4 August 2017.

44. Lal, R. Role of mulching techniques in tropical soil and water management. IITA Tech. Bull. 1975, 1, 1-38. Available online: https:/ / hdl.handle.net/10568/109316 (accessed on 17 November 2021).

45. Heinemann, W.H., Jr.; Gary, J.W.; Dilworth, A.E. Experimental machine for autodibble planting. Trans. ASAE 1973, 16, 656-659. [CrossRef]

46. Landers, J.N. Tropical Crop-Livestock Systems in Conservation Agriculture: The Brazilian Experiense; Food and Agriculture Organization of the United Nations-Integrated Crop Management: Roma, Italy, 2007; Volume 5, Available online: http://www.fao.org/3/a1 083e/a1083e.pdf (accessed on 17 November 2021).

47. Federal Republic of Brazil. Presidential Decree, N. 10.828 of 1.10.21. Available online: https://www.in.gov.br/en/web/dou/-/ decreto-n-10.828-de-1-de-outubro-de-2021-349986833 (accessed on 20 October 2021).

48. European Commission. Available online: https://ec.europa.eu/environment/soil/soil_policy_en.htm (accessed on 30 October 2021).

49. Chicago Council on Global Affairs. Global Food for Thought. Available online: https://www.thechicagocouncil.org/commentaryand-analysis/blogs/global-food-thought (accessed on 12 October 2021).

50. Lal, R. Soil Carbon Sequestration Impacts on Global Climate Change and Food Security. Science 2004, 304, 1623-1627. [CrossRef]

51. Akbarnia, A.; Farhani, F. Study of fuel consumption in three tillage methods. Res. Agr. Eng. 2014, 60, 142-147. [CrossRef]

52. Landers, J.N.; de Freitas, P.L.; Boddey, R. Potential for Mitigation of Deforestation and Negative Off-farm impacts with Conservation Agriculture: Employing Zero Tillage Farming in the Brazilian Cerrado. In Savannas and Dry Forests: Linking People with Nature; Mistry, J., Berardi, A., Eds.; Ashgate Publishing Ltd.: Aldershot, UK, 2006; Chapter 10; pp. 241-264. 
53. Primavesi, O. Crop-Livestock Integration Reduces Methane Emissions in Beef Cattle; Direto no Cerrado: Brasília, Brazil, 2008; Volume 50, pp. 16-17.

54. Davin, E.L.; Seneviratne, S.I.; Ciais, P.; Olioso, A.; Wang, T. Preferential cooling of hot extremes from cropland albedo management. Proc. Natl. Acad. Sci. USA 2014, 111, 9757-9761. [CrossRef]

55. Bragagnolo, N.; Pan, W.; Thomas, J.C. Solo, Uma Experiência em Manejo e Conservação; Ed. Bragagnolo: Curitiba, Brazil, $1997 ;$ p. 102.

56. Painter, K. Cargill Establishes New Carbon Measures and Money to Farmers Using Soil Health Practices. Available online: https: / / www.startribune.com/ cargill-establishes-new-carbon-measures-and-money-to-farmers-using-soil-health-practices / 600097892/?refresh=true (accessed on 19 September 2021).

57. Lal, R.; Smith, P.; Jungkunst, H.F.; Mitsch, W.J.; Lehmann, J.; Nair, P.K.R.; McBratney, A.B.; Sá, J.C.M.; Schneider, J.; Zinn, Y.L.; et al. The carbon sequestration potential of terrestrial ecosystems. J. Soil Water Conserv. 2018, 73, 145A-152A. [CrossRef]

58. Freitas, P.L.; Martin-Neto, L.; Manzatto, C.V. Solos: Além de tudo, sequestro de carbono. Rev. Agroanal. 2007, 27, E15E16. Available online: www.infoteca.cnptia.embrapa.br/infoteca/bitstream/doc/30637/1/Proci07.00111.pdf (accessed on 28 September 2021).

59. Paixão, F.A.; Soares, C.P.B.; Jacovine, L.A.G.; da Silva, M.L.; Leite, H.G.; da Silva, G.F. Quantificação do estoque de carbono e avaliação econômica de diferentes alternativas de manejo em um plantio de eucalipto. Rev. Árvore Viçosa Braz. 2006, 30, 411-420. [CrossRef]

60. United Nations Department of Economic and Social Affairs Sustainable Development. Available online: https://Sdgs.Un.Org/ Goals (accessed on 29 October 2021).

61. Evergreening the Earth: A Global Campaign to Restore Degraded Lands Worldwide. Available online: www.evergreening.org (accessed on 20 October 2021).

62. Macedo, M.C.M. Integração lavoura e pecuária: O estado da arte e inovações tecnológicas. R. Bras. Zootec. 2009, 38, 133-146. [CrossRef]

63. Landers, J.N.; Clay, J.; Weiss, J. Integrated Crop/Livestock Ley Farming with Zero Tillage: Five Case Studies of the Win-Win-Win Strategy for Sustainable Farming in the Tropics. In Proceedings of the III World Congress on Conservation Agriculture, Nairobi, Kenya, 3-7 October 2005; Available online: https:/ / www.researchgate.net/publication/313427158_Integrated_croplivestock_ley_ farming_with_zero_tillage_five_case_studies_of_the_win-win-win_strategy_for_sustainable_farming_in_the_tropics (accessed on 20 October 2021).

64. Landers, J.N.; Weiss, J. Study on the Conversion of Degraded Tropical Pastures to Productive Crop x Livestock Rotations and their Effect on Mitigating Deforestation. Unpublished document produced for the Worldwide Fund for Nature and The Nature Conservancy. 2001; p. 30.

65. Gurgel, A.C.; Laurenzana, R.D. Desafios e Oportunidades da Agricultura Brasileira de Baixo Carbono. In Agricultura, Transformação Produtiva e Sustentabilidade, 1st ed.; Vieira-Filho, J.E.R., Gasques, J.C., Eds.; IPEA: Brasilia, Brazil, 2016; Volume 1, pp. 343-366. Available online: http:/ / repositorio.ipea.gov.br/bitstream/11058/9262/1/Desafios\%20e\%20oportuniddes.pdf (accessed on 28 September 2021).

66. Polidoro, J.C.; de Freitas, P.L.; Hernani, L.C.; dos Anjos, L.H.C.; Rodrigues, R.A.R.; Cesário, F.V.; de Andrade, A.G.; Ribeiro, J.L. Potential impact of plans and policies based on the principles of conservation agriculture on the control of soil erosion in Brazil. Land Degrad. Dev. 2021, 3457-3468. [CrossRef]

67. Antille, D.L.; Peets, S.; Galambošová, J.; Botta, G.F.; Rataj, V.; Macak, M.; Tullberg, J.N.; Chamen, W.C.T.; White, D.R.; Misiewicz, P.A.; et al. Review: Soil compaction and controlled traffic farming in arable and grass cropping systems. Agron. Res. 2019, 17, 653-682. [CrossRef]

68. Weed Management the Organic Way. Available online: Rodaleinstitute.org/blog/weed-management-the-organic-way/ (accessed on 20 October 2021).

69. Reicosky, D.C.; Kemper, W.D.; Langdale, G.W.; Douglas, C.L.; Rasmussen, P.E. Soil organic matter changes resulting from tillage and biomass production. J. Soil Water Conserv. 1995, 50, 253-261.

70. Searchinger, T.D.; Wirsenius, S.; Beringer, T.; Dumas, P. Assessing the efficiency of changes in land use for mitigating climate change. Nature 2018, 564, 249-253. [CrossRef] [PubMed]

71. Newton, P.; Civita, N.; Frankel-Goldwater, L.; Bartel, K.; Johns, C. What Is Regenerative Agriculture? A Review of Scholar and Practitioner Definitions Based on Processes and Outcomes. Front. Sustain. Food Syst. J. 2020, 4, 194. [CrossRef]

72. Regenerative Agriculture Initiative; The Carbon Underground. What Is Regenerative Agriculture? Available online: https:// regenerationinternational.org/wp-content/uploads/2017/02/Regen-Ag-Definition-2.23.17-1.pdf (accessed on 10 August 2021).

73. Regeneration International. Available online: https:// regenerationinternational.org/why-regenerative-agriculture (accessed on 20 September 2021).

74. Thierfelder, C.; Baudron, F.; Setimela, P.; Nyagumbo, I.; Mupangwa, W.; Mhlanga, B.; Lee, N.; Gérard, B. Complementary practices supporting conservation agriculture in southern Africa. A review. Agron. Sustain. Dev. 2018, 38, 16. [CrossRef]

75. Kertész, A.; Madarász, B. Conservation Agriculture in Europe. Int. Soil Water Conserv. Res. 2014, 2, 91-96. [CrossRef]

76. Basch, G.; Kassam, A.; González-Sánchez, E.J.; Streit, B. Making Sustainable Agriculture Real in CAP 2010-The Role of Conservation Agriculture; ECAF: Brussels, Belgium, 2012; Available online: https://dspace.uevora.pt/rdpc/bitstream/10174/7730/1/CA\%20 and\%20CAP\%202020.pdf (accessed on 17 November 2021). 
77. Landers, J.N.; Saturnino, H.M.; de Freitas, P.L.; Trecenti, R. Experiences with farmer Clubs in Dissemination of Zero Tillage in Tropical Brazil. In Proceedings of the I World Congress on Conservation Agriculture, Madrid, Spain, 1-5 October 2001.

78. Glassa, L.M.; Newigaa, J. Governance for achieving the Sustainable Development Goals: How Important are Participation, Policy Coherence, Reflexivity, Adaptation and Democratic Institutions? 2019. Available online: https:// reader.elsevier.com (accessed on 22 October 2021).

79. Sustainable Agriculture Research and Education (SARE). Cover Crop Economics: Opportunities to Improve Your Bottom Line in Row Crops. Sare Technical Bulletin. 2019. Available online: https://www.sare.org/wp-content/uploads/Cover-CropEconomics.pdf (accessed on 17 November 2021). 